new type of car is to be standardised. It is estinated that the new type of car eliminates about ninety per cent of the noise inflicted upon passengers by the usual equipment. The new cars are said to be so noiseless that passengers can converse across the aisles without raising their voices. Doors and windows are kept closely shut. This excludes dirt and dust as well as noise. The ventilation is provided by electrically driven blowers suspended from the ceiling. The cost of installing the new equipment in the old type of car is about sixty pounds.

\section{Mining Research at Birmingham}

THE report of the work of the Mining Research Laboratory in the University of Birmingham during 1932 has been published. This is mainly financed by the British Colliery Owners' Research Association, and the investigations are largely addressed to the subjects of silicosis and nystagmus, which are costing the industry annually a very large sum of money. A great deal of work appears to have been done upon the determination of free silica in rocks, and it may be suggested that if the work of Dr. W. R. Jones, published in a recent number of the Journal of Hygiene, is supported by other observers, very much of this work may prove to be useless. On the other hand, the physiological and physical investigations on illuminations pronise to be of great help in the matter of nystagmus. Other matters which have been investigated are such important points as the extension of the use of coal, the investigation of spontaneous combustion, the production of dangerous atmospheres in the mine, suitable wetting agents, etc.; and are bound to be of service to the coal mining industry. The report gives the impression of a year's very energetic work.

\section{Industrial Design Competition}

The Royal Society of Arts has recently issued its report on the competition for industrial designs in 1933. For the six sections into which the competition was divided - architectural decoration, textiles, furniture, book production, advertising and commercial art and miscellaneous-2,623 designs were submitted by 1,131 competitors, of whom 724 were students of schools of art, Canada, Australia, New Zealand and South Africa being all represented. The report gives full details of the awards and much information about the prizes. Altogether a sum of $\mathfrak{1 1 , 6 1 4} 15 s .0 d$. was offered by the Society, the City Companies and various industrial firms, and since the competitions were started about ten years ago, the Society has expended about $£ 5,000$ on them. Unfortunately, for financial reasons the Council now finds it impossible to carry on the competitions, so none will be held in 1934. This is much to be regretted, for the competitions have proved of great educational value, and have proved that there is no lack of creative talent among the younger generation.

\section{Liver Preparations and Estrin}

WE have received from the British Drug Houses, Ltd., London, N.1, leaflets describing their preparations of liver for use in the treatment of anæmia and their preparation of estrin called "CEstroform". For the treatment of pernicious anæmia, there is available liver extract in the form of a powder or in solution for oral or parenteral administration : the former two are pharmacopœial preparations; the latter is issued in 1 c.c. ampoules, each equal in anti-anæmic activity to $50 \mathrm{gm}$. fresh liver. Estroform is a standardised preparation of ketohydroxyœstrin and is issued in ampoules for intramuscular or subcutaneous injection and in tablets for oral use, each ampoule or tablet containing 1,000 (international) units. Estroform is of value in certain disorders of menstruation, in the vomiting of pregnancy and in prematurity of infants.

\section{New Whale Hall at the Natural History Museum}

From January 1 the exhibit of whales at the Natural History Museum will be closed to the public, and the removal of the specimens to the Hall in the new building, which was completed two years ago, will be commenced. Owing to the difficult economic position which has existed since the completion of the new building, money has hitherto not been available either for the removal of the exhibited specimens or for their erection in the new Hall. Means have, however, now been found to enable a start to be made with the work. Moreover, the old iron building in which the whales and dolphins have been exhibited for thirty-five years past is shortly to be pulled down to make way for a permanent building which is intended to provide storage and study-space mainly for the Department of Entomology.

\section{Museum of Practical Geology}

Is consequence of the impending transfer of offices, library and collections of the Geological Survey of Great Britain from the Museum of Practical Geology, Jermyn Street, to the new Museum in South Kensington, London, the Museum of Practical Geology will be closed to the public on and after January 1. The Library of the Geological Survey will remain open to the public until the transfer of the books commences. Entrance will be through the door in Piccadilly.

\section{The Sky in January}

Venus, which has been a brilliant object in the sky during the last months of 1933, is now passing towards inferior conjunction, which is reached on February 5. The casual observer will see little of the planet until its next eastern elongation, but it will be a brilliant object in the early morning sky later in the year. By the middle of January, Mars will set about two hours after the sun; Jupiter will be an early morning object, rising six hours before the sun, and Saturn will be close to Mars in the evening sky. There will be a partial eclipse of the moon, partly visible at Greenwich, on January 30. The circumstances of this eclinse are as follows: Moon enters penumbra, 14h. 07m., leaves, $19 \mathrm{~h} .17 \mathrm{~m}$.; enters umbra, $16 \mathrm{~h} .01 \mathrm{~m}$., leaves, 17h. 20m. Middle of eclipse, 16h. 43m., magnitude, 0.12 (moon's diameter $=1$ ). 